\title{
A SUCCESSFUL PRACTICAL EXPERIENCE WITH DEDICATED GEOSTATIONARY OPERATIONAL ENVIRONMENTAL SATELLITES GOES-10 AND - 12 SUPPORTING BRAZIL
}

Simone M. S. Costa, Renato G. Negri, Nelson J. Ferreira, Timothy J. Schmit, Nelson Aral, Wagner Flauber, Juan Ceballos, Daniel Vila, Jurandir Rodrigues, luiz A. Machado, Sérgio Pereira, Marcus Jorge Bottino, Raffi Agop Sismanoglu, and Pedro Langden

The GOES-10 and - 12 experience improved the environmental monitoring of South America and demonstrated the importance of international scientific communication for advancing satellite meteorology.

$\mathrm{T}$ he National Oceanic and Atmospheric Administration (NOAA)'s National Environmental Satellite, Data, and Information Service (NESDIS) operates the Geostationary Operational Environmental Satellite (GOES) system, which provides continuous, timely, and high-quality Earth observation (Menzel and Purdom 1994). The GOES constellation consists of two operational geostationary satellites positioned over the equator (GOES-East usually stationed at $75^{\circ} \mathrm{W}$ and GOES-West at $135^{\circ} \mathrm{W}$ ) and also an onorbit spare. Each operational satellite views almost one-third of Earth's surface: GOES-West scans western North America and the Pacific Ocean while GOES-East covers eastern North and South America (SA) and most of the Atlantic Ocean. The most recent system (GOES-16, previously known as GOES-R), NOAA's newest geostationary satellite generation, is located at $90^{\circ} \mathrm{W}$ covering all the Americas and the eastern Pacific Ocean. It will be maintained in this test position until it is determined to become either the GOES-East or GOES-West operational satellite.

The two main sensors on board GOES's previous satellite generation are the imager and sounder (Menzel and Purdom 1994). For the GOES satellites focused on here (i.e., GOES-10 and -12), the imager is a five-channel imaging radiometer designed to sense radiant and solar-reflected energy from Earth with a spatial resolution from 1 (visible channel) to $4 \mathrm{~km}$ (middle and thermal infrared) at the equator, except for the GOES-10 water vapor (WV) channel at $8-\mathrm{km}$ resolution. The sounder is an instrument with 19 channels that provides data to determine the vertical temperature, moisture, and ozone profiles and cloudtop temperatures. 
Despite GOES being part of the U.S. operational geostationary satellite program, the eastern satellite component covers both Central and South America. In the 1980s, the Brazilian National Institute for Space Research (INPE) started to receive GOES downlink data from its local antenna. In the earliest days, GOES images were employed by INPE to supplement synoptic charts production, which previously were based only on data from a few sparse weather stations. GOES images improved substantially the understanding of synoptic weather systems over South America (Kousky and Kayano 1981; Kousky and Gan 1981; Kousky and Ferreira 1981). However, the effective use of digital satellite data in Brazil started only in the later 1990s, when GOES imagery was employed to derive products, such as fire spots, rainfall, and solar radiation. These GOES products were generated by aggregating Brazilian scientific knowledge on the received binary data in order to fulfill the weather information demand of various local public sectors, such as civil defense, water management, and energy services.

INPE received binary data from GOES-8, -10 , -11 , and -12 and currently from -13 . The institute is preparing a proposal to collaborate with NOAA in performing some postlaunch validation of the GOES16 products, while new antenna reception acquisition is planned in the coming years. GOES-10 and -12 were particularly the most useful meteorological satellites for Latin America. After their retirement as U.S. operational satellites, NOAA/NESDIS extended the satellites' mission to be exclusively dedicated to imaging South America. The use of GOES data to support Brazilian meteorology for more than three

affiliations: Costa, Negri, Ferreira, Arai, Ceballos, Vila, Rodrigues, Machado, Pereira, Sismanoglu, and Langden-Satellite and Environmental System Division, Center for Weather Forecast and Climate Studies, National Institute for Space Research, São Paulo, Brazil; SCHMIT- Advanced Satellite Products Branch, NOAA/NESDIS Center for Satellite Applications and Research, Madison, Wisconsin; Flauber-Climatempo, São Paulo, Brazil; Bottino-Centro Nacional de Monitoramento e Alertas de Desastres Naturais, São Paulo, Brazil CORRESPONDING AUTHOR: Simone M. S. Costa, simone.sievert@cptec.inpe.br

The abstract for this article can be found in this issue, following the table of contents.

DOI:I0.II75/BAMS-D-16-0029.I

In final form 16 June 2017

(C)2018 American Meteorological Society

For information regarding reuse of this content and general copyright information, consult the AMS Copyright Policy. decades (Fig. 1) is a practical demonstration of the long-standing partnership between international organizations [NOAA, National Aeronautics and Space Administration (NASA), University of Wisconsin (UW)/Cooperative Institute for Meteorological Satellite Studies (CIMSS), and INPE]. Therefore, the aim of this paper is threefold. First, it attempts to describe some of the technical and operational challenges faced by NOAA in extending the GOES-10 and -12 missions. Second, it aims to present INPE's experience on using the received satellites data for generating products for local weather decision-makers. Third, it addresses some main NOAA and INPE collaboration efforts for further advancing satellite meteorology.

This can be considered an extension of Schmit et al.'s (2009) work, which described various GOES10 applications after its retirement. However, this paper emphasizes the development and use of satellite products based on the Brazilian local reception GOES data stream.

\section{SOUTH AMERICA GOES EXTENDED SAT-} ELLITE MISSION. The first discussion concerning a possible extension of the GOES mission to SA occurred during NOAA's Satellite Direct Readout Conference: A Decade in Transition in 2004. This conference provided a forum for information exchange between NOAA and South and Central American GOES users equipped with direct broadcast reception systems. Three years later, the first satellite (GOES-10) was entirely dedicated to South America. To provide this dedicated service to SA, some technical and operational challenges had to be faced.

The first required technical operation was to maneuver the GOES-10 spacecraft over the equator from its original operational position $\left(135^{\circ} \mathrm{W}\right)$ to approximately $60^{\circ} \mathrm{W}$ in March 2007. GOES-10 was maintained at this position until December 2009, when it ran out of fuel and was placed into a supersynchronous orbit. To maintain an SA service, the successful GOES-10 maneuvering experience was repeated with GOES-12, which was also shifted from its original operational position $\left(75^{\circ} \mathrm{W}\right)$ to approximately $60^{\circ} \mathrm{W}$ in May 2010. GOES-12 operated in this position covering SA until August 2013, when it was deactivated. NOAA/NESDIS shifted both retired spacecraft to secure a continuous South American coverage because GOES-East only imaged south of the equator every $3 \mathrm{~h}$ when a severe weather event impacted North America (e.g., an Atlantic hurricane), leaving forecasters in South America at a disadvantage with less imagery. Both GOES were dedicated to SA operated continuously for 7 years without interruption. With 
GOES-10 and -12 dedicated to $\mathrm{SA}$, forecasters were able to receive images every $15 \mathrm{~min}$, with the exception of a 30-min full-disk scan once every $3 \mathrm{~h}$.

In the original operation position, GOES-10 and -12 presented mainly three standard-operation scan modes: routine-an image every $15 \mathrm{~min}$ of the continental United States, an image every $30 \mathrm{~min}$ of Central and South America (to approximately $50^{\circ} \mathrm{S}$ ), and a full-disk image every $3 \mathrm{~h}$; rapid scan operation (RSO) - an image every $7.5 \mathrm{~min}$; and super rapid scan operations (SRSO)approximately one image every minute. As mentioned above, when GOES RSO or SRSO is utilized, most of the Southern Hemisphere is not scanned. Therefore, another technical operation was required to implement new GOES-10 and - 12 scanning schedules.

With GOES-10 and -12 dedicated to SA, forecasters were able to receive images every $15 \mathrm{~min}$, with the exception of a 30 -min fulldisk scan once every $3 \mathrm{~h}$. This new schedule not only increased the time resolution from 30 and $15 \mathrm{~min}$ but also covered the southeastern viewing angle. Figure 2 shows the scanning configuration for GOES-10 and -12 dedicated to SA for 2007 and 2012, respectively. The images' longitude limits were shortened in order to cover approximately from $10^{\circ} \mathrm{N}$ to $75^{\circ} \mathrm{S}$ every $15 \mathrm{~min}$. Currently, the scanning routine defined for GOES-13 for South America is quite similar to that used in GOES-12 before its retirement in 2010.

Additionally, the extended usefulness of the GOES10 and -12 imagery to SA was only possible because of a new remapping system developed by NOAA (Tehranian et al. 2007). These two satellites have operated at significantly high inclination angles over South America, which required high image motion compensation (IMC) to geopositioning images. IMC compensates apparent image distortion caused by orbit and attitude motions of the spacecraft. However, GOES-10 and -12 exceeded the maximum designed IMC limit, which was no longer able to compensate in space the apparent image motions. NOAA developed an on-ground remapping system for correcting Earth's latitude and longitude locations of each picture element (pixel) within an image. INPE evaluated the performance of the remapped data by using operationally these GOES images for almost 7 years: from October 2007 to December 2009 for GOES-10 and from May 2010 to August 2013 for GOES-12.

Figure 3 shows the GOES-10 infrared (IR) image broadcasted by INPE before and after remapping. 
GOES-12 IR 10.7 23-11-2005 18:52 UTC

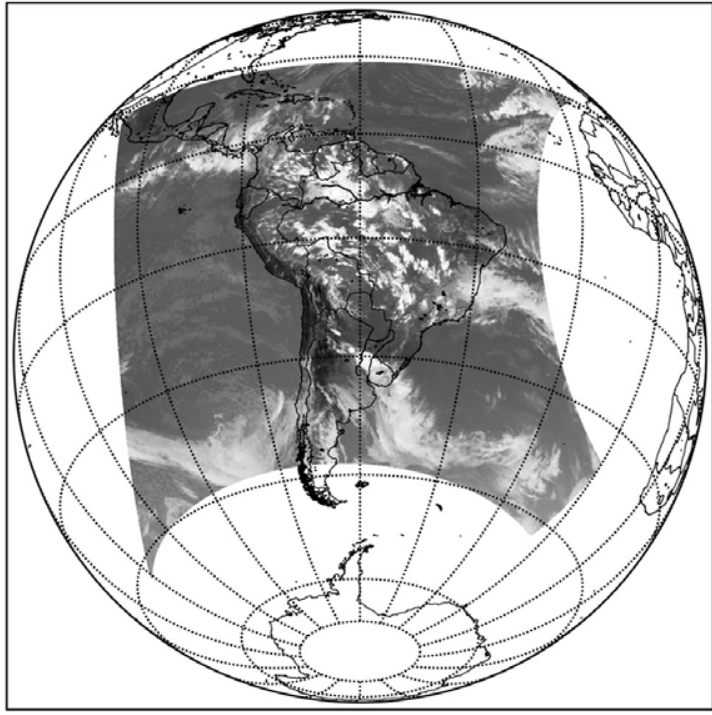

GOES-12 IR 10.7 12-12-2012 12:00 UTC

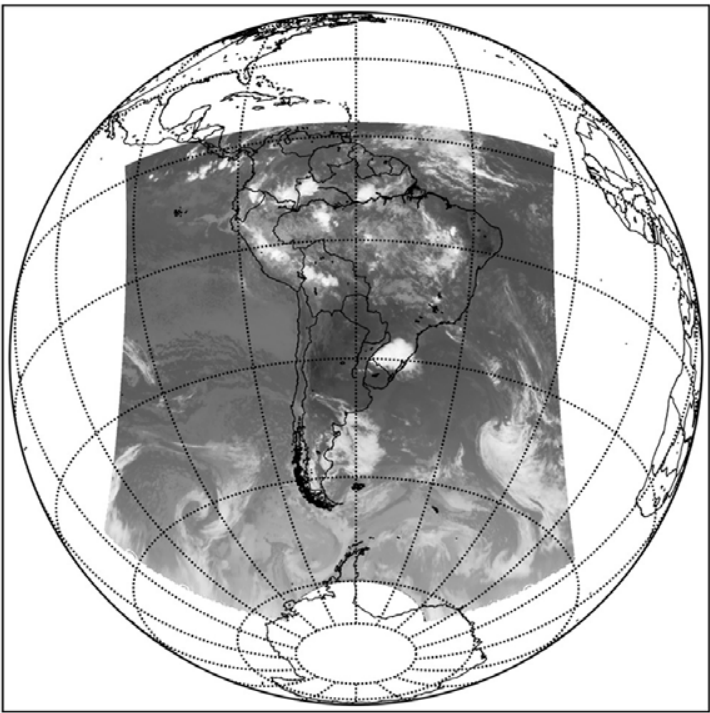

GOES-10 IR 10.7 07-07-2007 07:00 UTC

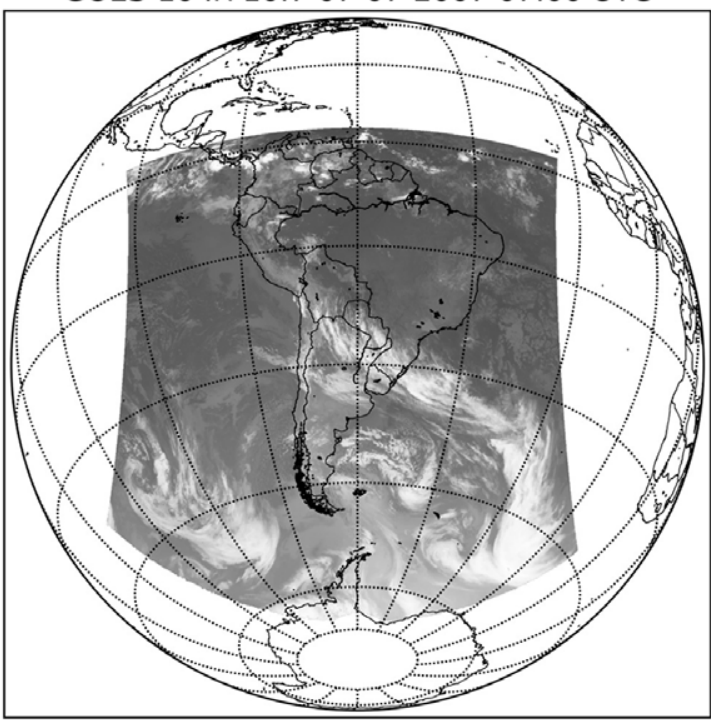

GOES-13 IR 10.7 10-11-2015 10:00 UTC

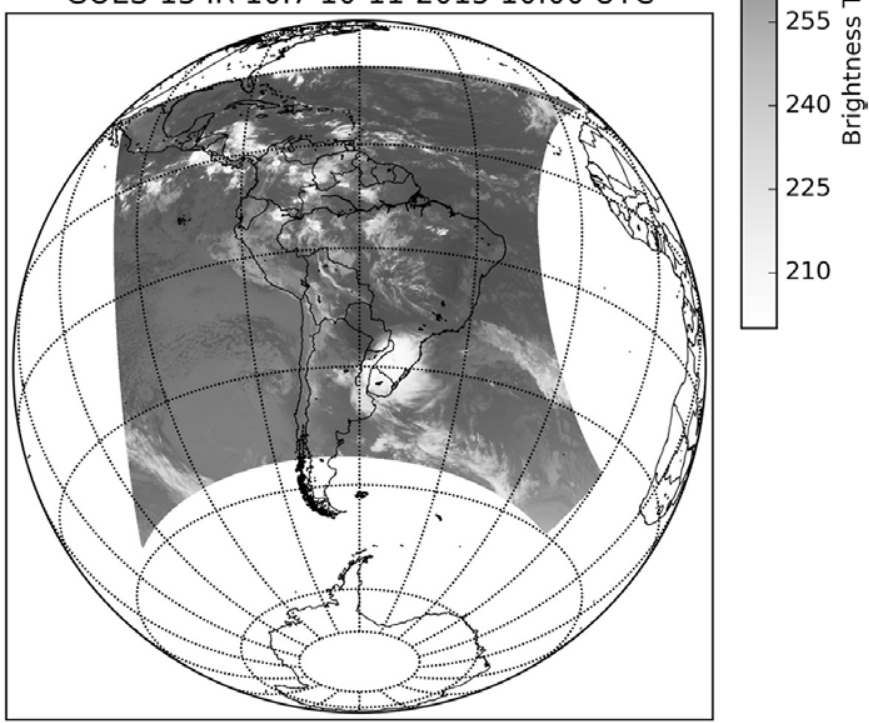

FIG. 2. Spatial coverage provided by (top left) GOES- 12 imager from its position at $75^{\circ} \mathrm{W}$, (top right) GOES-10 and (bottom left) GOES- 12 at $60^{\circ} \mathrm{W}$, and (bottom right) GOES- 13 at $75^{\circ} \mathrm{W}$. Images from GOES- 10 and -12 positioned at $60^{\circ} \mathrm{W}$ covered southern Argentina and Chile and part of the Antarctic Peninsula in contrast with GOES- 12 and -13 at $75^{\circ} \mathrm{W}$.

The un-remapped image is geographically displaced northward from the contour map used as reference. The new remapping technique corrects the image distortion. This was important mainly for fire detection location. Following on the success of the use by SA of the new remapping capability, the new-generation Advanced Baseline Imager on GOES-16 is employing a similar technique (Schmit et al. 2005, 2017).

These satellite orbital and attitude motions of the spacecraft also affected the INPE's data reception. INPE adapted the ground station antenna capability to change its elevation angle during the day to compensate the satellite north-south displacement.
Otherwise, the fixed-antenna operational mode could lose the satellite signal at some periods of the day making the reception impossible. This new capability allowed receiving images with minimum losses.

Since GOES-10 and - 12 were fully dedicated to SA, their data were no longer distributed and archived by NOAA. INPE took the responsibility to acquire, process, distribute, and archive GOES-10 and -12 data and products. Meanwhile, NOAA was still responsible for operating the satellites, processing the data, and rebroadcasting these data.

The practical and technological exchange experiences between NOAA and INPE described above 


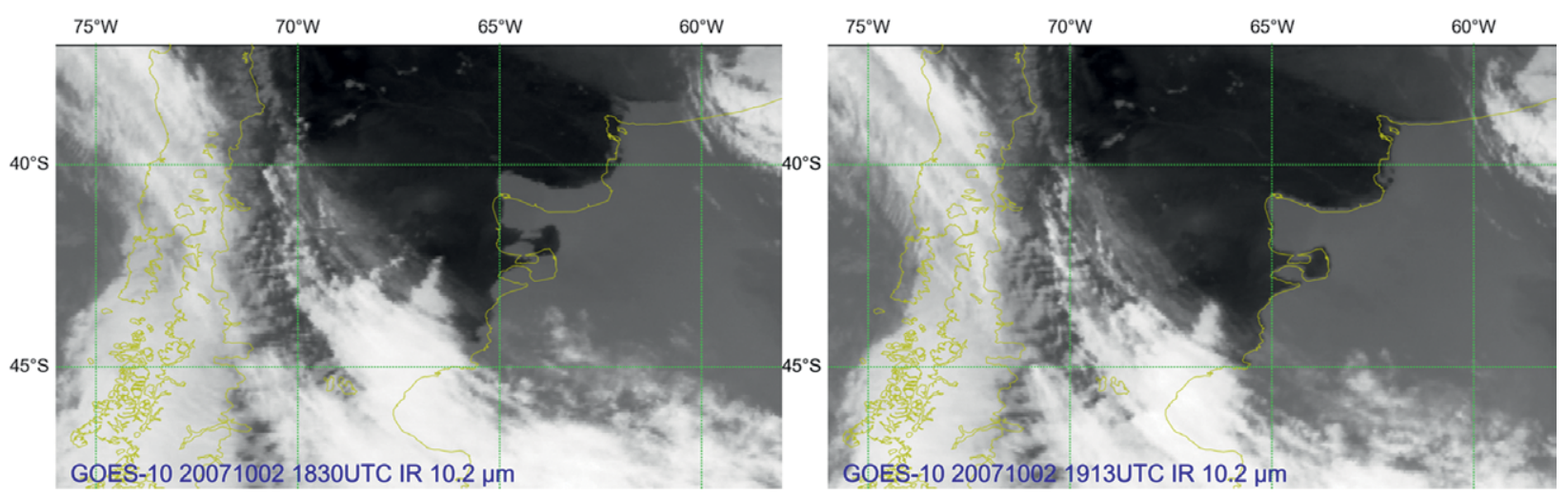

FIG. 3. GOES-10 infrared images for southern South America (left) before and (right) after ground remapping application.

should be recognized as a model of international collaborative work on meteorological satellite application and dissemination.

The three main benefits of GOES-10 and -12 for the South American users were the 15-min image frequency instead of the 30-min interval (even during RSO), the operational sounder, and the coverage area. The 15-min time resolution was important for monitoring the evolution of convective clouds whose life cycle could be shorter than the 3-h coverage obtained in RSO mode, when more frequent images of the United States were being generated. The spatial coverage including southern Argentina and Chile and part of the Antarctic Peninsula were monitored for the first time by geostationary satellite (Fig. 2). Therefore, the GOES-10 and -12 shifts provided South America with images of Earth's atmosphere system twice as frequently as before and covering nearly as far south as the Antarctic Peninsula (up to $75^{\circ} \mathrm{S}$ ). Additionally, operational satellite soundings were useful to complement upper-air observations, mainly in regions such as the Amazon basin. From these soundings, products such as total precipitable water-an important variable to describe the gaseous water contained in a vertical column of atmospherecould be generated. GOES-12 also had better nominal spatial resolution (4 $\mathrm{km}$ at nadir) of the water vapor channel in relation to GOES-10 (8 km), allowing INPE to improve some products, such as wind estimates and fire detection.

This NOAA endeavor not only improved the satellite coverage of the Western Hemisphere but also strengthened the World Meteorological Organization activities, such as World Weather Watch-designed to observe weather around the world-and the Global Earth Observing System of Systems (GEOSS) project-an international program aiming to ensure an integrated and sustained Earth observation system for the benefit of humankind activities (Lautenbacher 2006).

\section{APPLICATIONS OF GOES OVER BRAZIL.}

GOES imagery is one the most important satellite data sources used by operational meteorologists in SA. Routinely they employ visible (VIS), IR, and WV GOES imagery to have an instantaneous glimpse of the atmosphere state, at least from a qualitative perspective, in order to monitor weather system development and displacement. On the other hand, the size of the South American continent, the lack of regional meteorological satellites, and the sparse coverage of ground weather stations and radar have strongly motivated the use of GOES-derived products in Brazil. GOES products, such as rainfall estimation, lightning occurrence probability, radiation estimation, biomass burning detection, and atmospheric motion vectors (AMVs), are generated in quasi-real time by the Center for Weather Forecast and Climate Studies (CPTEC)-INPE to support forecasters and other meteorology-related activities.

These products are generated using GOES data received via the INPE local antenna. Some of these products are listed on Table 1, and their uses from a meteorological point of view are briefly described in this section. It is worth noting that some products have been generated locally for almost 20 years, approaching the time scales for climate studies.

Storm identification and tracking. Forecast and Tracking of Active Convective Cells (FORTRACC; Machado et al. 1998) is an automatic algorithm aimed to detect, track, and forecast severe convective events. It identifies storms' structural properties combining the temperature, size, and duration criteria using GOES IR and WV image sequences (Machado and Laurent 2004; Vila et al. 2008; Machado et al. 
TABLE I. Summary of the main characteristics of GOES-INPE-derived products available at CPTEC. Reference period: dedicated GOES-I0 (Mar 2007-Dec 2009) and GOES-I2 (May 2010-Aug 2013) for SA. In bold are the main reference papers that describe the development/adaptation of product algorithms applied to South America.

\begin{tabular}{|c|c|c|c|}
\hline Satellite data & $\begin{array}{l}\text { Channels } \\
\text { used }\end{array}$ & $\begin{array}{c}\text { Brief product description (source/developments for } \\
\text { South American application) }\end{array}$ & $\begin{array}{l}\text { Data } \\
\text { availability }\end{array}$ \\
\hline \multicolumn{4}{|c|}{ Level 0 and I: Raw and satellite data products } \\
\hline \multirow[t]{4}{*}{ Imagery } & \multirow[t]{4}{*}{$\mathrm{I}-4$} & Digital format & 1996-present \\
\hline & & Photo prints & $1979-96$ \\
\hline & & Negative film & $|979-9|$ \\
\hline & & Photo prints donated by NASA & $1966-74$ \\
\hline Sounding & $1-18$ & & $2007-12$ \\
\hline \multicolumn{4}{|c|}{ Nowcasting and weather forecasting products } \\
\hline Precipitation & IR & $\begin{array}{l}\text { NESDIS Hydroestimator, improved version (Vicente et al. } \\
\text { 1998) }\end{array}$ & 2003-present \\
\hline $\begin{array}{l}\text { Mesoscale convective } \\
\text { system }\end{array}$ & IR, WV & $\begin{array}{l}\text { Forecast and tracking active convective cells by analyzing their } \\
\text { radiative and morphological features (Machado et al. 2003; } \\
\text { Vila et al. 2005) }\end{array}$ & 2005-present \\
\hline \multirow[t]{2}{*}{$\begin{array}{l}\text { Lightning occurrence } \\
\text { risk }\end{array}$} & IR, WV & $\begin{array}{l}\text { Estimated from exponential fitting using brightness tempera- } \\
\text { ture (BT) difference between WV and IR and light ground } \\
\text { measurements (Machado et al. 2008) }\end{array}$ & 2008-present \\
\hline & & $\begin{array}{l}\text { Mesoscale convective system (MCS) physical and microphysical } \\
\text { properties analyzed to forecast atmospheric electrical activi- } \\
\text { ties (Mattos and Machado } 201 \mathrm{I} \text { ) }\end{array}$ & \\
\hline \multirow[t]{2}{*}{$\begin{array}{l}\text { Atmospheric wind } \\
\text { vector }\end{array}$} & VIS, NIR, IR & $\begin{array}{l}\text { Wind speed and direction estimated by tracking cloud or wa- } \\
\text { ter vapor structures in a successive image sequence (Schmetz } \\
\text { et al. 1993; Laurent 1993) }\end{array}$ & 1998-present \\
\hline & & $\begin{array}{l}\text { Adapted to SA using GOES images (Machado and Ceballos } \\
\text { 2000) and extended to VIS and NIR channels (Negri and } \\
\text { Machado 2008) }\end{array}$ & \\
\hline Atmospheric sounding & $\begin{array}{c}1-18 \\
\text { (sounder) }\end{array}$ & $\begin{array}{l}\text { Physical interactive method (Ma et al. 1999) with covariance error } \\
\text { matrix adapted to SA (Gonçalves et al. 20I2) }\end{array}$ & $2007-12$ \\
\hline \multicolumn{4}{|c|}{ Solar and terrestrial radiation } \\
\hline Cloud classification & VIS, NIR, IR & $\begin{array}{l}\text { Clustering method applied to selected supervised scene, includ- } \\
\text { ing different clouds and surfaces (Bottino and Ceballos 2014) }\end{array}$ & 2000-present \\
\hline Solar radiation & VIS & $\begin{array}{l}\text { Physical model based on VIS imagery to estimate global surface } \\
\text { solar radiation (Ceballos et al. 2004) }\end{array}$ & 1999-present \\
\hline Sunshine duration & VIS & $\begin{array}{l}\text { Linear relation between cloud cover and observed reflectance at } \\
\text { VIS channel (Ceballos and Rodrigues 2008) }\end{array}$ & 2007-present \\
\hline $\begin{array}{l}\text { Outgoing longwave } \\
\text { radiation }\end{array}$ & IR & 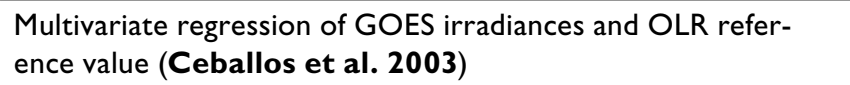 & 1997-present \\
\hline \multicolumn{4}{|c|}{ Monitoring vegetation fires } \\
\hline Fire detection & VIS, NIR, IR & $\begin{array}{l}\text { Based on multichannel brightness temperature threshold } \\
\text { (Setzer and Yoshida 2004) }\end{array}$ & 1998-present \\
\hline
\end{tabular}

2009a,b). FORTRACC has been employed operationally in Argentina, Brazil (Machado et al. 2009a), and Peru and tested in India (Goyal et al. 2016). Since GOES-10 and -12 imaged the SA atmosphere more frequently than any other GOES, the storm tracking by FORTRACC was improved. This is because the time interval between two consecutive images was reduced from 30 to $15 \mathrm{~min}$, allowing better identification of the convective system.

Figure 4 shows an example of a mesoscale convective system over northeast Brazil and the Atlantic Ocean tracked by FORTRACC. According to those criteria, the system life cycle phase is classified as intensifying because its area is expanding (Fig. $4 \mathrm{~b}$, 

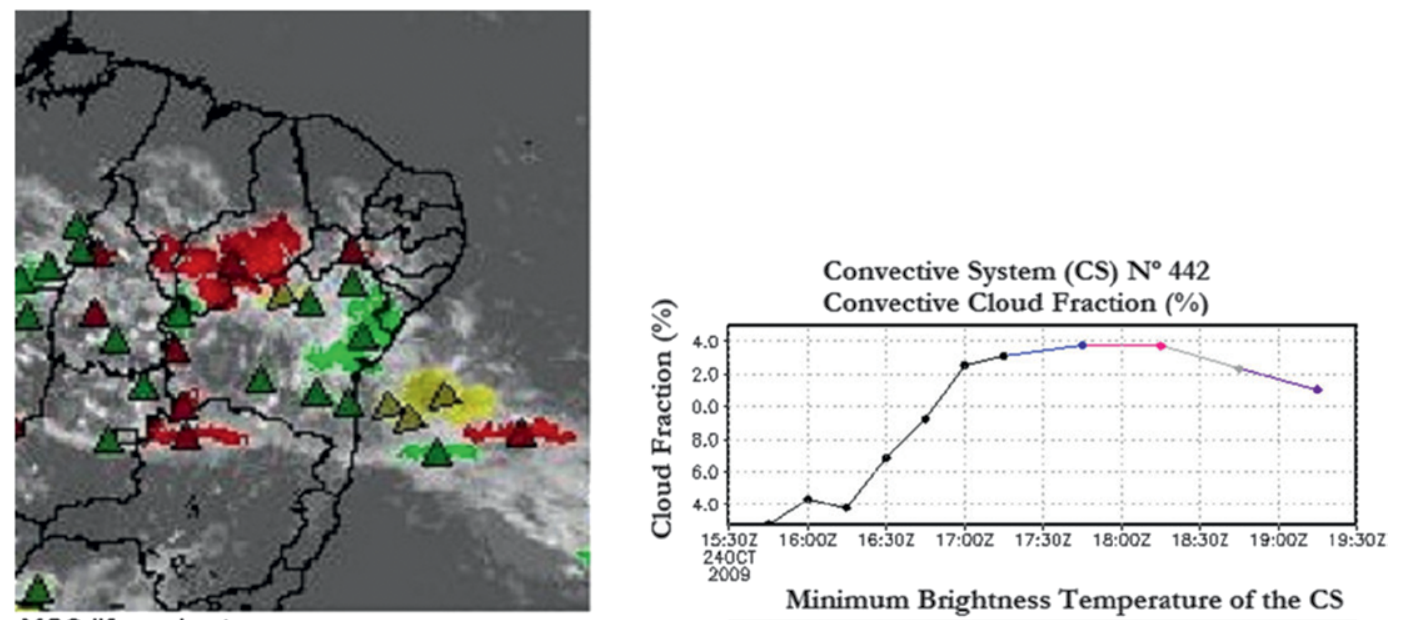

MSC life cycle stages

Dissipating $\square$ Mature $\square$ Intensifying

(a)
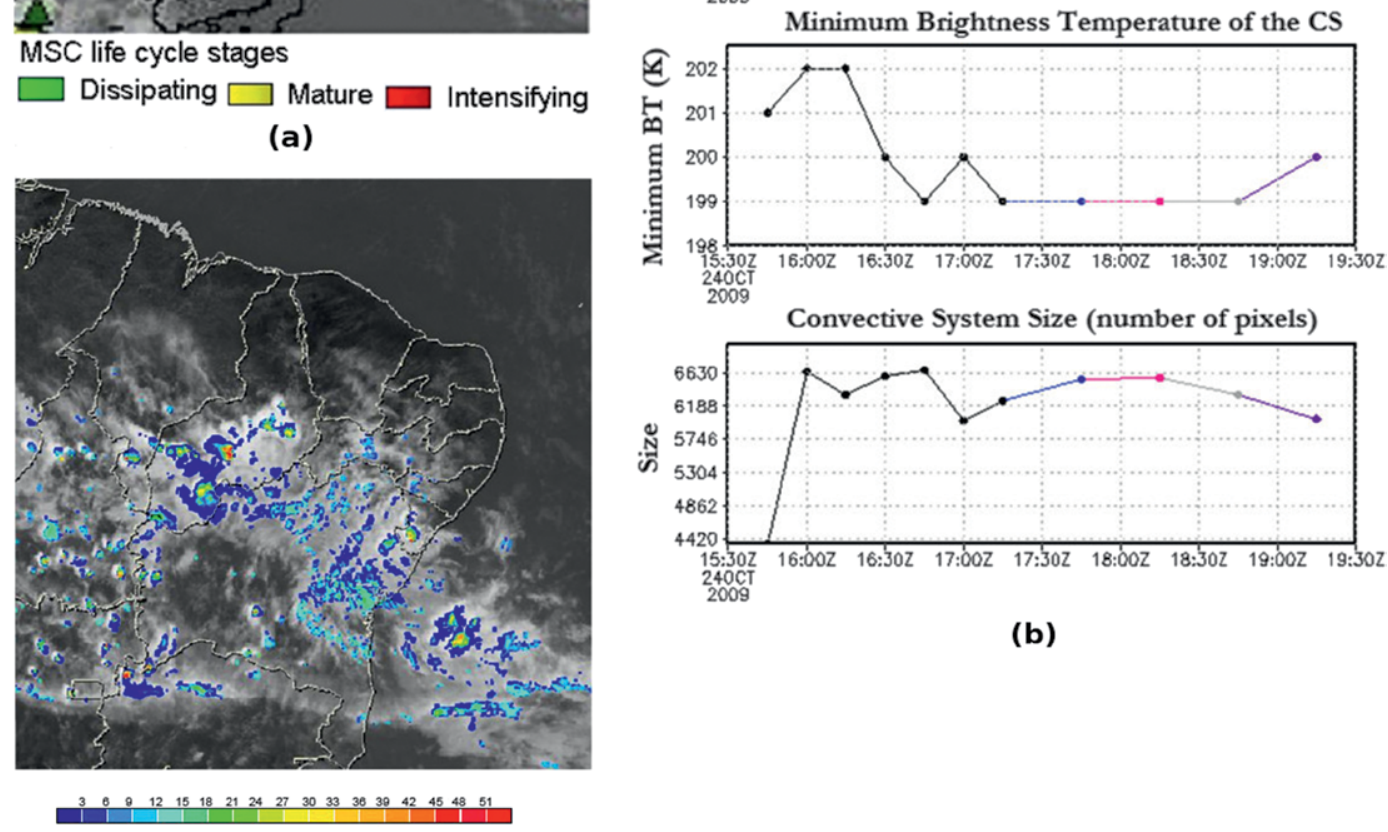

(b)

(c)

FIG. 4. (a) Composition of GOES-IO IR image and cloud cluster detection using FORTRACC at I7I5 UTC 24 Oct 2009. (b) Temporal evolution of mesoscale convective system morphological and radiative convective cloud fraction, minimum brightness temperature, and convective system area in number of pixels (properties monitored in black and forecasted for different lead times-30, 90, 60, and $120 \mathrm{~min}$-in color). (c) Instantaneous rainfall at $1715 \mathrm{UTC}\left(\mathrm{mm} \mathrm{h}^{-1}\right)$.

bottom) and its temperature is decreasing (Fig. $4 \mathrm{~b}$, middle). The convective fraction increases maintaining persistent cloud-top minimum temperatures of around $200 \mathrm{~K}$. FORTRACC predicts that the system remains stable for the next $120 \mathrm{~min}$, and its lifetime is estimated to be up to $3 \mathrm{~h}$. The rainfall inferred by GOES at 1715 UTC associated with this convective system is around $40 \mathrm{~mm} \mathrm{~h}^{-1}$ (Fig. $4 \mathrm{c}$ ).

Rainfall. Precipitation intensity is derived based on the improved version of the NESDIS hydroestimator (Vicente et al. 1998). It uses a nonlinear power-law equation that relates cloud-top brightness temperature from the IR GOES channel and radar-derived rainfall-rate estimates. Although the technique accuracy is limited to the use of the $10.8-\mu \mathrm{m}$ channel, the high temporal and spatial resolution are important points to be considered compared with passive microwave (PMW) sensors, which are more accurate for precipitation estimation. Those sensors [Special Sensor Microwave Imager/Sounder (SSMIS), Global Precipitation Measurement (GPM) Microwave Imager (GMI), Advanced Microwave Scanning Radiometer (AMSR-2), among others] are present in polar and equatorial orbiters with a temporal resolution of two to four times per day (depending on satellite), while the spatial resolution is larger than $10 \mathrm{~km}$ (depending on the selected channel frequency). On the other 


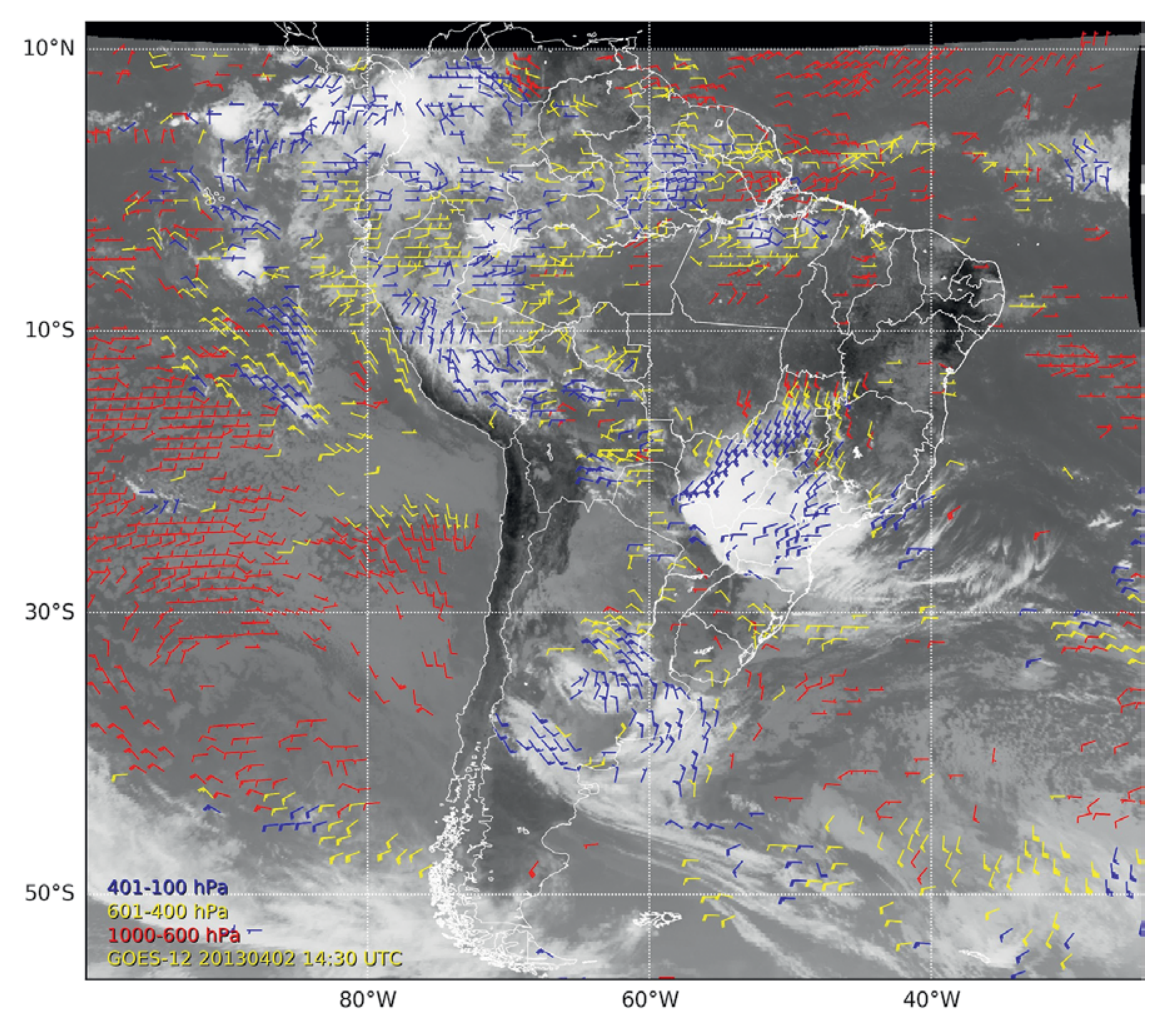

Fig. 5. Atmospheric motion vectors obtained at 1430 UTC 2 Apr 2013 from GOES-I2.Pressure levels: 100-400 (blue), 400-600 (yellow), and 600-1,000 hPa (red). through overhead power lines that are vulnerable to storms and electrical discharges.

Temperature and humidity column vertical distribution (sounding). CPTEC-INPE produced operational atmospheric soundings over SA using the GOES-10 and -12 sounder. Soundings over this region were inferred nearly continuously in time, which had not been possible previously with polar-orbiting satellites. GOES-10 and -12 sounding retrievals were performed by an adapted version of the physical-statistical iterative algorithm based on the classic Gauss-Newton method developed by CIMSS at the University of Wisconsin (Ma et al. 1999). For good performance over SA, the

hand, for some critical applications like nowcasting, the latency (time between the acquisition of the image and the product delivery) is also an important factor. While direct readout (DRO) of geostationary orbit allows a fast data acquisition and product delivery, for some PMW sensors the DRO option is not available, seriously affecting the real-time applications. (For more information about satellite orbits and sensor characteristics, see www.wmo-sat.info/oscar /spacecapabilities.)

The rainfall product has been employed by agricultural and hydroelectric power companies and for research, educational, and climate monitoring purposes (Borús et al. 2004; Vila et al. 2005; Falck et al. 2015, 2016).

Atmospheric electrical activity. Atmospheric electrical activity is estimated based on the convective clouds' brightness temperature difference between IR and WV channels (Machado et al. 2009; Mattos and Machado 2011). This product has been a valuable tool for different societal segments directly affected by lightning activities, such as the electricity distribution system operators and telecommunications sectors. This product is mainly relevant to the Brazilian energy sector since most electrical energy is transmitted algorithm was adjusted to the South American meteorological conditions (Gonçalves et al. 2012).

Atmospheric motion vectors (AMVs). Atmospheric motion vectors are based on the advanced algorithm version developed by the European Space Operations Centre (Schmetz et al. 1993; Laurent 1993). The algorithm was improved at CPTEC-INPE (Machado and Ceballos 2000; Laurent et al. 2002; Negri and Machado 2008) using cloud or water vapor structures tracked from successive image sequences as tracers to estimate the wind speed and direction. Wind information is very important to monitor in real time the growth of short waves, normally associated with intense convection.

Figure 5 shows an example of GOES-12 AMV product over SA. The 1,000-600-hPa AMVs clearly show the main mesoscale dynamics features, mainly the easterly wind over the tropics and the anticyclone associated with the southeast Pacific subtropical high along the coast of Chile-Peru. This product has been assimilated into CPTEC-INPE global numerical weather forecast models and also disseminated through the Global Telecommunications System, which is a coordinated global telecommunication system for rapid collection, exchange, and distribution of meteorological 
data. This locally inferred product reduces the latency for data assimilation. Negri et al. (2014) presents a new methodology for retrieving very high-resolution AMVs employing Spinning Enhanced Visible and Infrared Imager (SEVIRI)Meteosat Second Generation (MSG) multichannel combinations. It is expected that this methodology will be applied to the GOES16 imager to obtain inner cloud-top structures over SA.

Solar radiation. GOES VIS and IR imagery continuous availability since 1998 allowed CPTEC-INPE to develop methods for operational assessment of solar radiation (Fig. 6; Ceballos et al. 2004), sunshine duration (Ceballos and Rodrigues 2008; Porfírio and Ceballos 2012), and outgoing longwave radiation (Ceballos et al. 2003). GOES-10 and -12 South American data were particularly useful, since their higher frequency

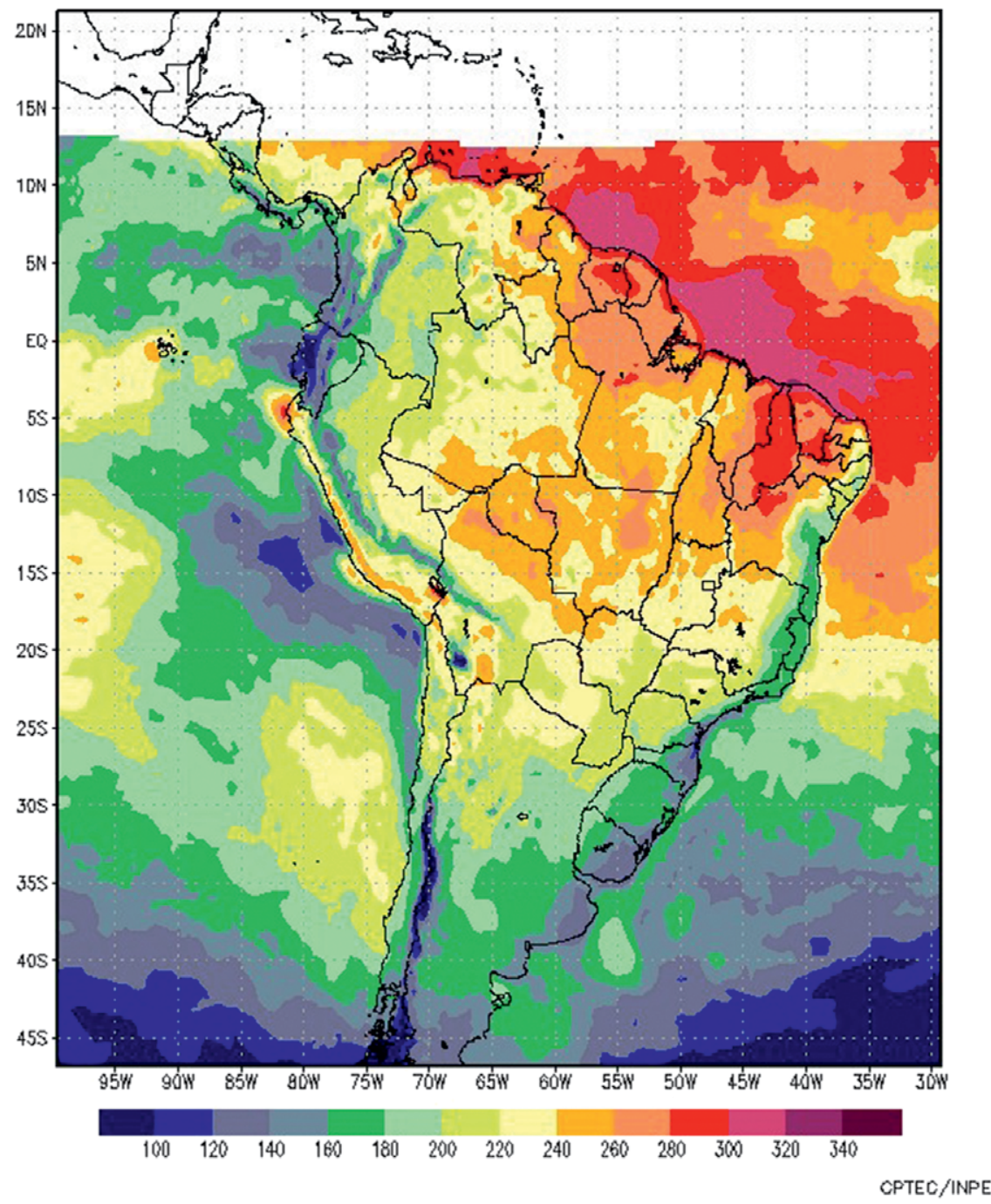

FiG. 6. Monthly mean global solar radiation $\left(\mathrm{W} \mathrm{m}^{-2}\right)$ over South America inferred using Gobal Radiation Model (GL), Sep 2008. allowed better daily integration of solar irradiance. Currently a solar radiation time series of 19 years is available covering South America and neighboring oceanic areas (Ceballos 2008). This product has been used in a broad range of applications, such as atmospheric circulation model evaluation and data assimilation (Tarasova et al. 2006), climatological studies (Pinto et al. 2010), renewable energy (Ortega et al. 2010), and agricultural management.

Vegetation and fires. A fire detection technique was developed at INPE (Setzer and Yoshida 2004) using GOES VIS, NIR, and IR channels. Figure 7 shows the number of GOES-10 fire pixels for two distinct years over Brazil. Nearly 65,000 fire pixels were detected in August 2007, while less than 7,500 were detected for the same month in 2009. Climatologically, the year of 2009 was considered wet, resulting in high soil moisture unfavorable to biomass burning. Although one could

argue that the decrease of fire occurrence in 2009 was associated to reduction via deforestation. Fire detection products are used by Brazilian governmental agencies, especially forest institutions, civil defense, and the army, to monitor and protect natural areas, conservation units, and indigenous land. Additionally, the fire detection location is used as input to an atmospheric chemical transport model (Freitas et al. 2017).

CASE STUDIES. CPTEC-INPE has high demand to support the Brazilian government with meteorological information to monitor severe weather and natural disasters. Two case studies are presented here as illustrations.

Hurricane Catarina was the first documented hurricane in the South Atlantic Ocean since geostationary satellite records began in the 1970s (Silva Dias et al. 2004). During the event, GOES-12 was operating 

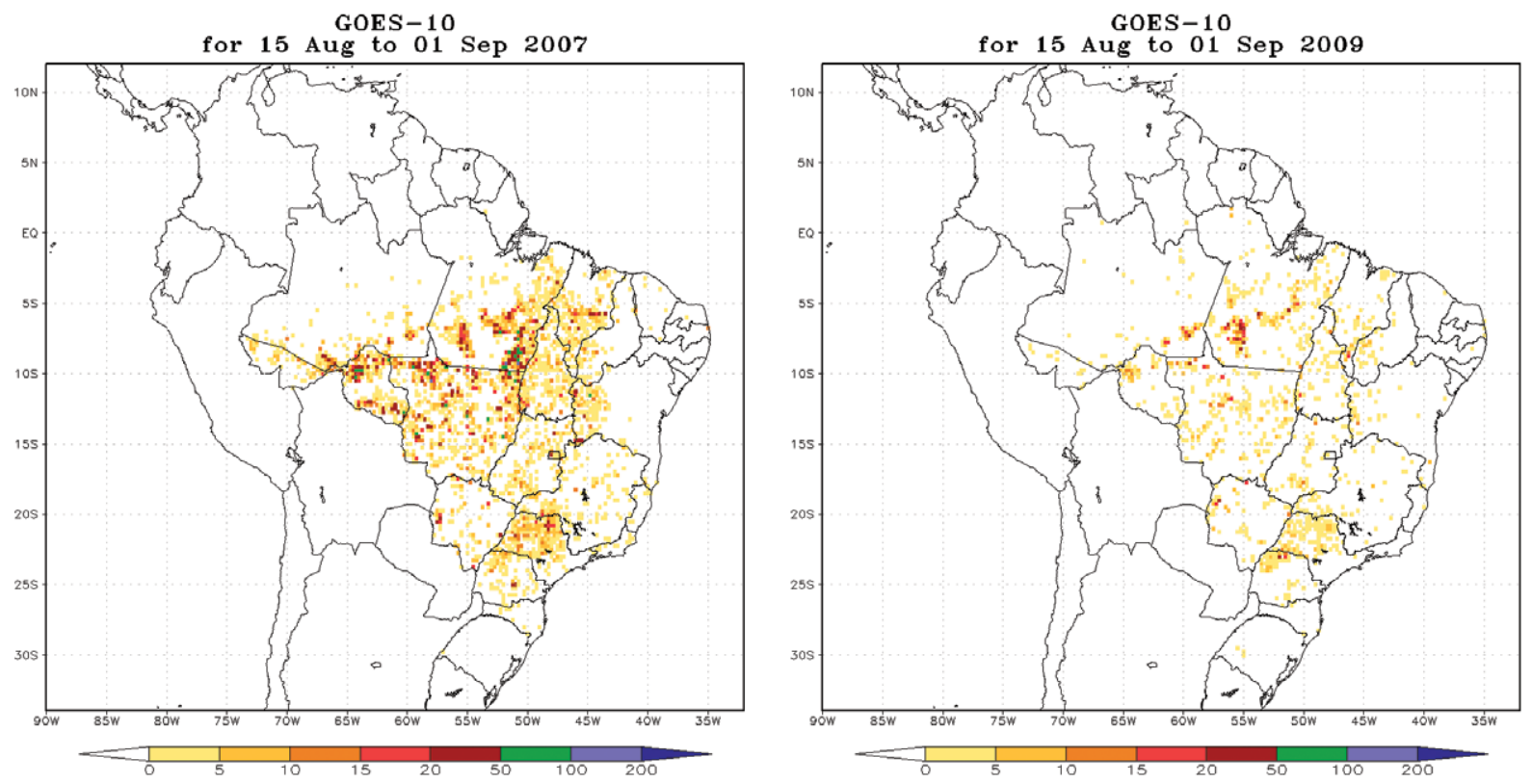

Fig. 7. Fire occurrence detection over Brazil (left) from I5 Aug to I Sep 2007 and (right) from I5 Aug to I Sep 2009. Bars are the number of hot spots for $25-\mathrm{km}$ grid size. The largest amount of biomass burning across Brazil occurs in Aug and Sep. The wet year of $\mathbf{2 0 0 9}$ was unfavorable to biomass burning; the number of fire spots was approximately 7,500 (and around 65,000 for 2007).

as GOES-East. Figure 8 shows Hurricane Catarina moving westward toward the Brazilian coastline. It emerged off the coast of Brazil (around $30^{\circ} \mathrm{S}, 45^{\circ} \mathrm{W}$ ) on 20 March 2004 (Pezza and Simmonds 2005; McTaggart-Cowan et al. 2006; Pezza et al. 2009; Filho et al. 2010). A nearly stationary low pressure system acquired tropical characteristics and developed into

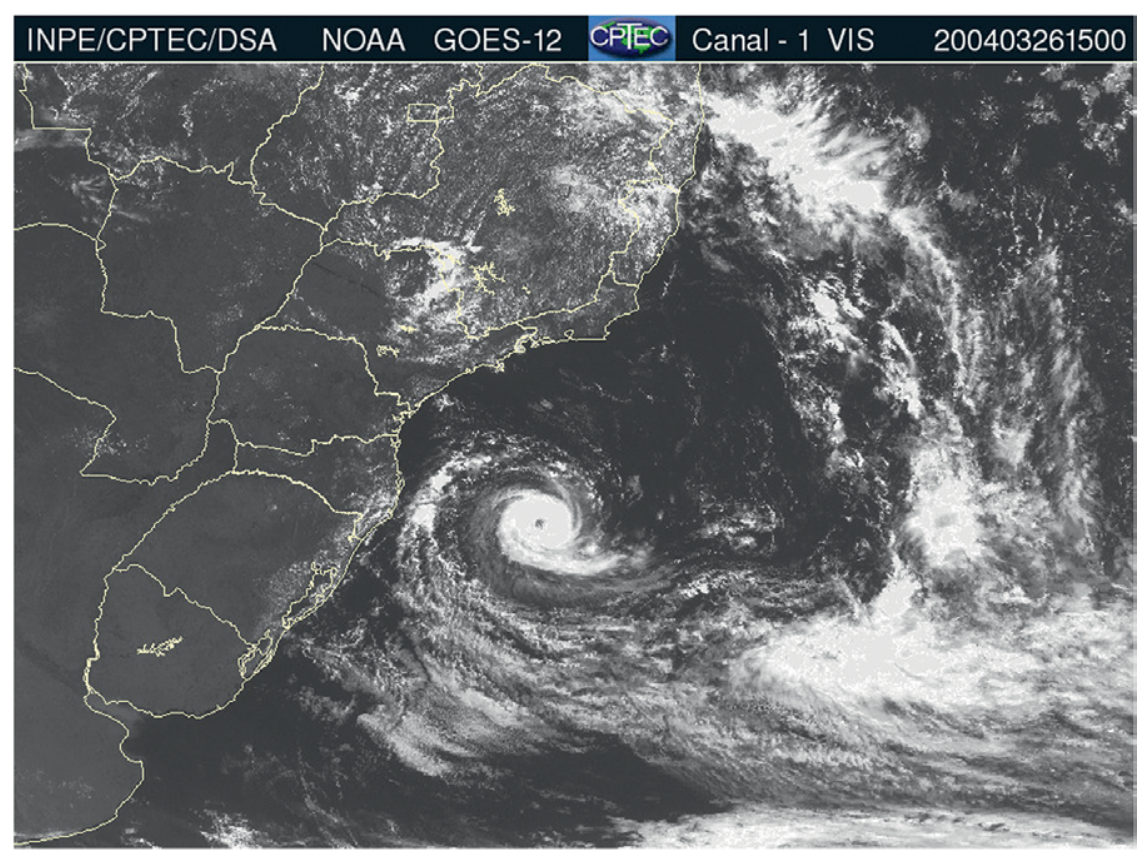

FIG. 8. Hurricane Catarina over the Atlantic Ocean at I500 UTC 26 Mar 2004. a hurricane by 26 March. Maximum sustained winds were estimated between 120 and $130 \mathrm{~km} \mathrm{~h}^{-1}(65-70$ $\mathrm{kt}$ ) with wind gusts of $155 \mathrm{~km} \mathrm{~h}^{-1}$ (85 kt) on $28 \mathrm{March}$, and the center of the storm made landfall later that day. Hurricane Catarina rapidly weakened upon landfall and dissipated the next day. GOES-12 provided timely coverage of Hurricane Catarina and helped Brazilian officials warn the public about the approaching storm. The storm impact was quite severe, and it left more than 2,000 people homeless and damaged nearly 1,500 public buildings and private businesses (Sociedade Brasileira de Meteorologia 2005).

Volcanic ash traces monitoring, June 20II. The volcano Puyehue-Cordón Caulle located in the Andes Mountains of southern Chile erupted several times during June 2011. It released high gas and aerosol concentrations seriously affecting airline flights and civil activities in South America. 
GOES-12 images together with a chemical transport model [Coupled Aerosol and Tracer Transport Model within the Brazilian Developments on the Regional Atmospheric Modeling System (CATT-BRAMS); Freitas et al. 2017] were used to monitor in real time the volcanic ash traces and predict possible risk areas (Costa et al. 2012; Pavani et al. 2016). The Argentinean Naval Hydrographic Service (SHN) in collaboration with the Argentinean National Meteorological Service also explored the GOES imagery coupled with an ash dispersion model to monitor this event (Collini et al. 2015). The model results were made available to the Buenos Aires Volcanic Ash Advisory Center and other end users.

\section{OTHER COLLABORATIVE ACTIVITIES BE-} TWEEN INPE AND NOAA. INPE has received and stored GOES data since the 1970s (Table 1). Image data are available in the form of negative film for photos from February 1979 to December 1991, photo prints between March 1979 and June 1996, and digital type from January 1996 to the present. Photo copies can be requested by email. Digital data are freely available as quicklook figures (jpeg) as well as in binary format, and they can be bulk downloaded up to 2,000 megabytes (at http://satelite.cptec.inpe.br /home/index.jsp). There is also a special satellite image dataset in photo print type covering the period from December 1966 to December 1974 donated to INPE by the University of Wisconsin-Madison Space Science and Engineering Center (UW-SSEC).

In the context of NOAA and INPE collaboration efforts, four other activities should be addressed. First, NOAA sponsored the training course in 2007 entitled "GEOSS Americas/Caribbean Remote Sensing Workshop-Transforming Data into Products." The course was hosted by CPTEC-INPE and had the strong collaboration of the UW-SSEC. Representatives from 12 Central and South American countries attended this training event.

Second, the capability of the use of the sounder on GOES (specifically, Visible Infrared Spin-Scan Radiometer Atmospheric Sounder) to derive goodquality water vapor and wind fields (Schmit et al. 1990) was first demonstrated in the late 1980s during the Amazon Boundary Layer Experiment (Garstang et al. 1990; Martin et al. 1994) — conducted by NASA in collaboration with INPE and the National Institute for Amazonian Research (INPA).

Third, INPE supported the development of a proxy dataset for the Geostationary Lightning Mapper (GLM) on board the new GOES-R generation (now on GOES-16). The GLM is the first operational lightning mapper ever flown in space (Goodman et al. 2012). During the fourth Cloud Processes of the Main Precipitation Systems in Brazil: A Contribution to Cloud-Resolving Modeling and to the GPM (CHUVA) field campaign project (Machado et al. 2014), ground lightning observations deployed across São Paulo (Brazil) combined with overpasses of the Tropical Rainfall Measuring Mission Lightning Imaging Sensor and Spinning Enhanced Visible and Infrared Imager on the Meteosat Second Generation provided a unique proxy dataset that has been used to develop and validate the GLM operational algorithm (Chronis et al. 2015; Albrecht et al. 2015; Bailey et al. 2014).

Finally, INPE and NOAA have been collaborating on the GEONETCast, the integrated strategy of the World Meteorological Organization for free satellite data dissemination and distribution over Latin American and African countries (http://satelite.cptec inpe.br/geonetcast/es/). INPE installed around 20 GEONETCast stations to support Brazilian regional meteorological centers in receiving free near-realtime environmental and Earth observation data. Considering the high cost of the antenna reception, GEONETCast is going to disseminate the GOES-16 data (https://geonetcast.wordpress.com/category (goes-r/).

FINAL REMARKS. This paper emphasizes the usefulness of the GOES-derived products benefiting various productive sectors in South America, such as agricultural industries, government, environmental groups, and energy management. Additionally, it illustrates the practical exchange of experience between scientists from the United States and Brazil for advancing Earth's monitoring system through development of novel software and products.

Dedicating GOES-10 and - 12 to South America is a remarkable demonstration on this international effort conducted by NOAA in the scope of WMO. The historical time series of the GOES data allows further development of climatological products for SA. Experience acquired by CPTEC-INPE in GOES-derived products described in this paper will be extremely valuable for developing new science and products with the new GOES-R generation (Schmit et al. 2017).

Currently, GOES-13 is the U.S. operational GOES-East satellite, and it is being successfully used in Brazil. During NOAA's satellite conference and WMO Executive Council meeting in 2013, South American users had the opportunity to highlight the impact of losing GOES-12 data and the data gap when GOES-13 is in RSO. Concerning this matter, NOAA 
has reviewed the GOES-East imager schedule during RSO to provide two additional short SA images per hour scanned at different time. These images are used to create a mosaic image, which certainly is an improvement over one image every $3 \mathrm{~h}$ for SA during RSO. But it covers only a part of the continent. Nowcasting applications, such as storm tracking and wind, are seriously affected. In the long term, this serious limitation in image frequency acquisition for SA is expected to be solved by the advent of GOES-R.

ACKNOWLEDGMENTS. NOAA/NESDIS is gratefully acknowledged for the operation of GOES-10 and -12 and adding the special GOES-East SA sectors, producing the GVAR data, and generating new scan schedules and for the on-ground navigation. NOAA/NESDIS's commitment and effort in maintaining these satellites in operation for the SA benefit are greatly recognized. We wish to thank from NOAA Chris Wheeler, Kevin Ludlum, Keith McKenzie, Cynthia L. Hampton, Thomas Renkevens, Yo Kung John Tsui, Hyre Bysal, Eric Madsen, and Jennifer S. Lewis; CIMSS-UW and NASA are also thanked for strong collaboration on the use of satellite data over Brazil. CNPq, CAPES, and FAPESP are thanked for researcher financial support. There are not enough words of gratitude for those researchers, technicians, engineers, and students that contributed to satellite meteorology in Brazil. Reviewers are thanked for their suggestions and comments, which significantly contributed to improving the publication quality. The views, opinions, and findings contained in this paper are those of the authors and should not be construed as an official National Oceanic and Atmospheric Administration or U.S. government position, policy, or decision. (More information on the GEOSS Americas/ Caribbean Remote Sensing Workshop-Transforming Data into Products workshop can be found at https://cimss .ssec.wisc.edu/rss/geoss/. South America real-time imagery and products can be found at http://satelite.cptec.inpe.br /home/novoSite/index.jsp.)

\section{REFERENCES}

Albrecht, R. L., C. A. Morales, M. M. F. Saba, and H. Holler, 2015: Evaluating lightning detection signatures at different technologies: A contribution to GOES-R and MTG. Joint MTG LI Mission Advisory Group \& GOES-R GLM Science Team Workshop, Rome, Italy, EUMETSAT, EUM/RSP/AGN/14/778115.

Bailey, J. C., and Coauthors, 2014: São Paulo Lightning Mapping Array (SP-LMA): Network assessment and analyses for intercomparison studies and GOES-R proxy activities. Proc. Int. Conf. on Atmospheric Electricity, Norman, OK, DB133E-10-SE-2455.
Borús, J., M. U. Quirno, D. Goniadzki, and D. Vila, 2004: Hydrologic modeling for flood warning and reservoir management. Instituto Nacional del Agua Tech. Doc., 13 pp.

Bottino, M. J. and J. C. Ceballos, 2014: Daytime cloud classification over South American region using multispectral GOES-8 imagery. Int. J. Remote Sens., 36, 1-19, https://doi.org/10.1080/01431161.2014.978953.

Ceballos, J. C., 2008: Time series of daily mean solar irradiance over South America: Some results of 11 years of CPTEC GL Model using GOES imagery. Proc. Int. Radiation Symp. 2008, Foz do Iguacu, Brazil, American Institute of Physics, http://mtc-m16c.sid.inpe.br /col/sid.inpe.br/mtc-m18@80/2008/10.13.18.11/doc /Cebs_11yrGL_IRS08-1.pdf.

—- and M. L. Rodrigues, 2008: Estimativa de insolação mediante satélite geoestacionário: resultados preliminares. Proc. XV Congresso Brasileiro de Meteorologia, São Paulo, Brazil, Brazilian Society of Meteorology, http://pyata.cptec.inpe.br/radiacao /docs/Cebs_Rodr_insolacao_15CBMET2008.pdf.

—, W. F. A. Lima, and J. M. Souza, 2003: Outgoing longwave radiation at the top of the atmosphere: Preliminary assessment using GOES- 8 Imager data. Rev. Bras. Geofís., 21, 53-64.

—, M. J. Bottino, and J. M. Souza, 2004: A simplified physical model for assessing solar radiation over Brazil using GOES 8 visible imagery. J. Geophys. Res., 109, D02211, https://doi.org/10.1029/2003JD003531. Chronis, T., T. Lang, W. Koshak, R. Blakeslee, H. Christian, E. McCaul, and J. Bailey, 2015: Diurnal characteristics of lightning flashes detected over the São Paulo lightning mapping array. J. Geophys. Res. Atmos., 120, 11799-11 808, https://doi.org/10.1002/2015JD023960.

Collini, E., M. S. Osores, A. Folch, J. G. Viramonte, G. Villarosa, and G. Salmuni, 2013: Volcanic ash forecast during the June 2011 Cordón Caulle eruption. Nat. Hazards, 66, 389-412, https://doi.org/10.1007 /s11069-012-0492-y.

Costa, S. M. S., W. F. A. Lima, S. R. Freitas, J. C. Ceballos, and J. V. Rodrigues, 2012: Monitoramento dos traços de cinzas do vulcão chileno Puyehue-Cordón Caulle. Proc. XVII Congresso Brasileiro de Meteorologia, Rio Grande do Sul, Brazil, Brazilian Society of Meteorology, P24-182.

Falck, A. S., V. Maggioni, J. Tomasella, D. A. Vila, and F. L. R. Diniz, 2015: Propagation of satellite precipitation uncertainties through a distributed hydrologic model: A case study in the Tocantins-Araguaia basin in Brazil. J. Hydrol., 527, 943-957, https://doi .org/10.1016/j.jhydrol.2015.05.042.

—, D. A. Vila, J. Tomasella, and V. Maggioni, 2016: Avaliação de um modelo estocástico de erro 
multidimensional aplicado a estimativas de precipitação por satélite. Rev. Bras. Meteor., 31, 52-63, https://doi .org/10.1590/0102-778620140042.

Filho, A. J. P., J. Pereira, A. B. Pezza, I. Simmonds, R. S. Lima, and M. Vianna, 2010: New perspectives on the synoptic and mesoscale structure of Hurricane Catarina. Atmos. Res., 95, 157-171, https://doi.org/10.1016/j .atmosres.2009.09.009.

Freitas, S. R., and Coauthors, 2017: The Brazilian developments on the Regional Atmospheric Modeling System (BRAMS 5.2): An integrated environmental model tuned for tropical areas. Geosci. Model Dev., 10, 189-222, https://doi.org/10.5194/gmd-10 $-189-2017$.

Garstang, M., and Coauthors, 1990: The Amazon Boundary-Layer Experiment (ABLE 2B): A meteorological perspective. Bull. Amer. Meteor. Soc., 71, 19-32, https://doi.org/10.1175/15200477(1990)071<0019:TABLEA>2.0.CO;2.

Gonçalves, W., S. M. S. Costa, C. F. Angelis, J. Rodrigues, and R. de Souza, 2012: Regionalization of the GOES10 retrieval algorithm for tropical South America. Int. J. Remote Sens., 33, 5366-5378, https://doi.org /10.1080/01431161.2012.657367.

Goodman, S. J., and Coauthors, 2012: The GOES-R Proving Ground: Accelerating user readiness for the Next Generation Geostationary Environmental Satellite System. Bull. Amer. Meteor. Soc., 93, 1029-1040, https://doi.org/10.1175/BAMS-D-11-00175.1.

Goyal, S., A. Kumar, G. Sangar, and M. Mohapatra, 2016: Severe thunderstorm activity over Bihar on 21st April, 2015: A simulation study by satellite based nowcasting technique. Remote Sensing of the Atmosphere, Clouds, and Precipitation VI, E. Im, R. Kumar, and S. Yang, Eds., International Society for Optics and Photonics (SPIE Proceedings, Vol. 9876), 987612, https://doi.org/10.1117/12.2222740.

Kousky, V. E., and N. J. Ferreira, 1981: Interdiurnal surface pressure variation in Brazil: Their spatial distribution, origins and effects. Mon. Wea. Rev., 109, 1999-2008, https://doi.org/10.1175/15200493(1981)109<1999:ISPVIB>2.0.CO;2.

— vortices in the tropical South Atlantic. Tellus, 33A, 538-551, https://doi.org/10.3402/tellusa.v33i6.10775.

— , and T. Kayano, 1981: A climatological study of the tropospheric circulation over the Amazon region. Acta Amazonica, 11, 743-758, https://doi.org/10 .1590/1809-43921981114743.

Laurent, H., 1993: Wind extraction from Meteosat water vapor channel image data. J. Appl. Meteor., 32, 11241133, https://doi.org/10.1175/1520-0450(1993)032 $<1124$ :WEFMWV>2.0.CO;2.
— , N. Arai, L. A. T. Machado, and M. Gondim, 2002: Wind extraction using satellite images in CPTEC: New version and evaluation with WETAMC/LBA and operational DSA/CPTEC data. Sixth Int. Winds Workshop, Madison, WI, International Winds Working Group, http://pyata.cptec.inpe.br/vento/docs /workshopwinds2.pdf.

Lautenbacher, C. C., 2006: The global earth observation system of systems: Science serving society. Space Policy, 22, 8-11, https://doi.org/10.1016/j.spacepol .2005.12.004.

Ma, X. L., T. J. Schmit, and W. L. Smith, 1999: A nonlinear physical retrieval algorithm-Its application to the GOES-8/9 sounder. J. Appl. Meteor., 38, 501-513, https://doi.org/10.1175/1520-0450(1999)038<0501:AN PRAI $>2.0 . \mathrm{CO} ; 2$.

Machado, L. A. T., and J. Ceballos, 2000: Satellite-based products for monitoring weather in South America: Winds and trajectories. Fifth Int. Winds Workshop, Lorne, VIC, Australia, International Winds Working Group, http://cimss.ssec.wisc.edu/iwwg/iww4/p93 -100_Machado-Satellite.pdf.

_ , and H. Laurent, 2004: The convective system area expansion over Amazonia and its relationships with convective system life duration and high-level wind divergence. Mon. Wea. Rev., 132, 714-725, https:// doi.org/10.1175/1520-0493(2004)132<0714:TCSAEO $>2.0 . \mathrm{CO} ; 2$.

— W. Rossow, R. L. Guedes, and A. Walker, 1998: Life cycle variations of mesoscale convective systems over the Americas. Mon. Wea. Rev., 126, 1630-1654, https://doi.org/10.1175/1520-0493(1998)126<1630:LC VOMC >2.0.CO;2.

— C. F. Angelis, and W. F. Lima, 2009a: A severe storm warning system based in radar and satellite data. Current Problems in Atmospheric Radiation: Proc. Int. Radiation Symp., Foz do Iguaçu, Brazil, American Institute of Physics, 400-403, https://doi .org/10.1063/1.3117004.

— W. F. A. Lima, O. Pinto, and C. A. Morales, 2009b: Relationship between cloud-to-ground discharge and penetrative clouds: A multi-channel satellite application. Atmos. Res., 93, 304-309, https://doi.org /10.1016/j.atmosres.2008.10.003.

— , and Coauthors, 2014: The CHUVA Project: How does convection vary across Brazil? Bull. Amer. Meteor. Soc., 95, 1365-1380, https://doi.org/10.1175/BAMS -D-13-00084.1.

Martin, D. W., T. J. Schmit, B. Goodman, N. J. Ferreira, and K. F. Brueske, 1994: A satellite-based estimate of evapotranspiration over Amazonia. Remote Sens. Rev., 10, 179-191, https://doi.org/ 10.1080 /02757259409532244. 
Mattos, E. V., and L. A. T. Machado, 2011: Cloud-to-ground lightning and mesoscale convective systems. Atmos. Res., 99, 377-390, https://doi.org/10.1016/j.atmosres .2010.11.007.

McTaggart-Cowan, R., L. F. Bosart, C. A. Davis, E. H. Atallah, J. R. Gyakum, and K. A. Emanuel, 2006: Analysis of Hurricane Catarina (2004). Mon. Wea. Rev., 134, 3029-3053, https://doi.org/10.1175/MWR3330.1.

Menzel, W. P., and J. F. W. Purdom, 1994: Introducing GOES-I: The first of a new generation of geostationary operational environmental satellites. Bull. Amer. Meteor. Soc., 75, 757-781, https://doi.org/10.1175/1520 -0477(1994)075<0757:IGITFO>2.0.CO;2.

Negri, R. G., and L. A. T. Machado, 2008: Estimativa do vento para os baixos níveis utilizando imagens dos canais visível e infravermelho próximo $3.9 \mu \mathrm{m}$. Rev. Bras. Meteor., 23, 206-218, https://doi.org/10.1590 /S0102-77862008000200008.

,$- \ldots$, and R. Borde, 2014: Inner convective system cloud-top wind estimation using multichannel infrared satellite images. Int. J. Remote Sens., 35, 651-670, https://doi.org/10.1080/01431161.2013.871391.

Ortega, R. E., S. Colle, and S. L. Abreu, 2010: The state of energy resource assessment in Chile. Renewable Energy, 35, 2514-2524, https://doi.org/10.1016/j .renene.2010.03.022.

Pavani, C. A. B., S. R. Freitas, W. F. A. Lima, S. M. S. C. Coelho, M. C. Yoshida, and N. M. E. Rosario, 2016: Incluindo funcionalidades no modelo BRAMS para simular o transporte de cinzas vulcânicas: Descrição e análise de sensibilidade aplicada ao evento eruptivo do Puyehue em 2011. Rev. Bras. Meteor., 31, 377-393, https://doi.org/10.1590/0102-778631231420150035.

Pezza, A. B., and I. Simmonds, 2005: The first South Atlantic hurricane: Unprecedented blocking, low shear and climate change. Geophys. Res. Lett., 32, L15712, https://doi.org/10.1029/2005GL023390.

_,- , and A. J. P. Filho, 2009: Climate perspective on the large-scale circulation associated with the transition of the first South Atlantic hurricane. Int. J. Climatol., 29, 1116-1130, https://doi.org/10.1002/joc.1757.

Pinto, L. I. C., M. H. Costa, L. M. F. Diniz, G. C. Sediyama, and F. F. Pruski, 2010: Comparação de produtos de radiação solar incidente à superfície para a América do Sul. Rev. Bras. Meteor., 25, 469-478, https://doi.org/10.1590/S0102-77862010000400006.

Porfírio, A. C. S., and J. C. Ceballos, 2012: Comparação entre diferentes métodos de estimativa de insolação: Uma aplicação às estações de Petrolina e Natal. Proc. XVII Congresso Brasileiro de Meteorologia, Gramado, Rio Grande do Sul, Brazil, Brazilian Society of Meteorology, http://plutao.sid.inpe.br/col/dpi.inpe.br /plutao/2012/11.28.13.45.38/doc/64ET.pdf.
Sociedade Brasileira de Meteorologia, 2005: Phenomenon Catarina in debate. Sociedade Brasileira de Meteorologia, accessed 24 December 2006, https://web.archive.org/web/20070701122232/www .sbmet.org.br/publicacoes/informativo/2005_07 /index_en.html.

Schmetz, J., K. Holmlund, J. Hoffman, B. Strauss, B. Mason, V. Gaertner, A. Koch, and L. V. D. Berg, 1993: Operational cloud-motion winds from Meteosat infrared images. J. Appl. Meteor., 32, 1206-1225, https://doi.org/10.1175/1520-0450(1993)032<1206:OC MWFM>2.0.CO;2.

Schmit, T. J., K. F. Brueske, W. L. Smith, and W. P. Menzel, 1990: Visible and infrared spin scan radiometer atmospheric sounder water vapor and wind fields over Amazonia. J. Geophys. Res., 95, 17 03117 038, https://doi.org/10.1029/JD095iD10p17031.

—, M. M. Gunshor, W. P. Menzel, J. J. Gurka, J. Li, and A. S. Bachmeier, 2005: Introducing the nextgeneration Advanced Baseline Imager on GOES-R. Bull. Amer. Meteor. Soc., 86, 1079-1096, https://doi .org/10.1175/BAMS-86-8-1079.

- , and Coauthors, 2009: Many uses of the geostationary operational environmental satellite-10 sounder and imager during a high inclination state. J. Appl. Remote Sens., 3, 033514, https://doi. org/10.1117/1.3099709.

—, P. Griffith, M. M. Gunshor, J. M. Daniels, S. J. Goodman, and W. J. Lebair, 2017: A closer look at the ABI on GOES-R. Bull. Amer. Meteor. Soc., 98, 681698, https://doi.org/10.1175/BAMS-D-15-00230.1.

Setzer, A., and M. C. Yoshida, 2004: Detecção de queimadas nas imagens do satélite geoestacionário GOES-12. National Institute for Space Research, accessed 20 June 2016, http://queimadas.cptec.inpe .br/ rqueimadas/documentos/relat_goes.htm.

Silva-Dias, P. L., M. A. Silva-Dias, M. Seluchi, and F. O. Assis-Diniz, 2004: Ciclone Catarina: Análise preliminar da estrutura, dinâmica e previsibilidade. Proc. XIII Congresso Brasileiro de Meteorologia, Fortaleza, Brazil, Brazilian Society of Meteorology, http://mtc-m16b.sid.inpe.br/col/cptec.inpe.br /walmeida/2004/09.21.09.13/doc/0000000764.doc.

Tarasova, T. A., J. P. R. Fernandez, I. A. Pisnichenko, J. A. Marengo, J. C. Ceballos, and M. J. Bottino, 2006: Impact of new solar radiation parameterization in the Eta Model on the simulation of summer climate over South America. J. Appl. Meteor. Climatol., 45, 318-333, https://doi.org/10.1175/JAM2342.1.

Tehranian, S., J. L. Carr, S. Yang, A. Swaroop, and K. Mckenzie, 2007: XGOHI, extended GOES highinclination mission for South-American coverage. 23rd Conf. on Interactive Information Processing 
Systems, San Antonio, TX, Amer. Meteor. Soc., 5A.1, https://ams.confex.com/ams/87ANNUAL/techprogram/paper_118129.htm.

Vicente, G. A., R. A. Scolfield, and W. P. Menzel, 1998: The operational GOES infrared rainfall estimation technique. Bull. Amer. Meteor. Soc., 79, 1883-1898, https://doi.org/10.1175/1520-0477(1998)079<1883:TO GIRE $>2.0 . C O ; 2$.

Vila, D. A., C. F. Angelis, J. Borus, and M. U. Quirno, 2005: Satellite rainfall estimation for operational use in flood warning and reservoir management. 2005 Fall Meeting, San Francisco, CA, Amer. Geophys. Union, Abstract GC41A-0387, http://adsabs.harvard. edu/abs/2005AGUFMGC41A0387V.

— , L. A. T. Machado, H. Laurent, and I. Velasco, 2008: Forecast and Tracking the Evolution of Cloud Clusters (ForTraCC) using satellite infrared imagery: Methodology and validation. Wea. Forecasting, 23, 233-245, https://doi.org/10.1175/2007WAF2006121.1.

\section{NEW FROM AMS BOOKS!}

\section{"A thoughtful analysis of actions that we need to take to reduce the impacts of extreme weather...a must-read for everyone with an interest in the weather and climate." \\ - FRANKLIN W. NUTTER, \\ President, Reinsurance Association of America}

\section{Living on the Real World: How Thinking and Acting Like Meteorologists Will Help Save the Planet WILLIAM H. HOOKE}

Meteorologists sift through a deluge of information to make predictions every day. Instead of being overwhelmed by the data and possibilities, they focus on small bits of information while using frequent collaboration to make decisions. With climate change a reality, William $\mathrm{H}$. Hooke suggests we look to the way meteorologists operate as a model for how we can solve the twenty-first century's most urgent environmental problems. 


\section{Science at Your Fingertips}

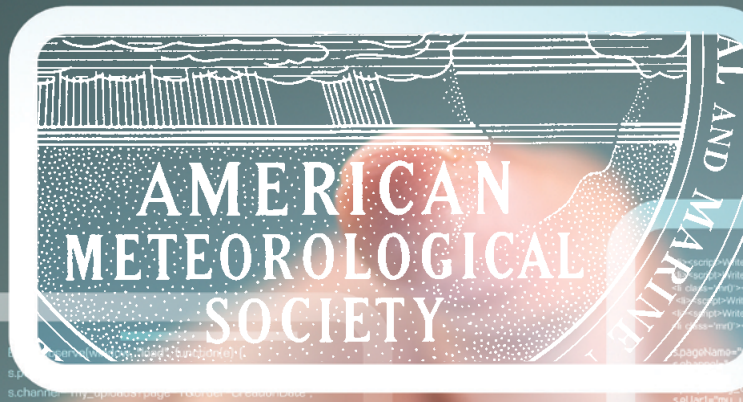

\section{AMS Journals are}

now optimized for viewing on your mobile device.

Access journal articles, monograph titles, and BAMS content using your iOS, Android, or Blackberry phone, or tablet.

Features include:

- Saving articles for offline reading

- Sharing of article links via email and social networks

- Searching across journals, authors, and keywords

And much more...

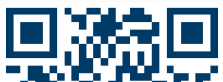
gror 마. 直社
Scan code to connect to journals.ametsoc.org
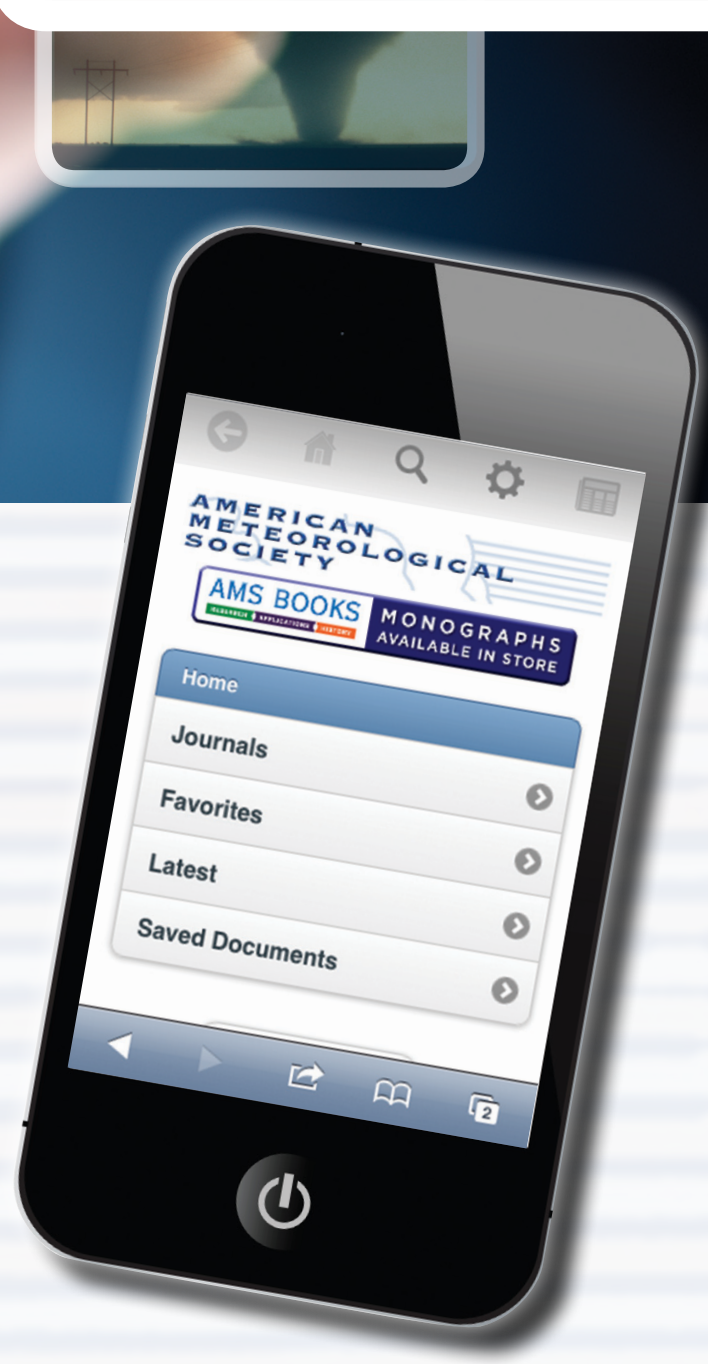

A MERICAN METEOROLOGICAL SOCIETY 